\title{
ANALYSIS OF RELATIONSHIP BETWEEN THREE DIMENSIONS OF QUALITY, USER SATISFACTION, AND E-LEARNING USAGE OF BINUS ONLINE LEARNING
}

\author{
Yosep \\ Department of Information Systems, Binus Graduate Programs, Bina Nusantara University \\ Jakarta 11480, Indonesia. Email: yosep.yoseyo@gmail.com
}

\begin{abstract}
Information technology has affected various sectors including the education sector. In the sector, information technology has brought us long distance education, which relies heavily on the use of e-learning management system. In Indonesia, Bina Nusantara University is the first and foremost long distance education institution. The institution has been developing and using an e-learning management system for a number of years. This work intends to evaluate to which extent the system is able to enhance e-learning experiences. We adopted the DeLone and McLean's Information System success model and empirically measured the relation between the aspects of system quality, information quality, service quality, user satisfaction, and net benefits. From a population of the size 311 students, we have collected 149 responses using questionnaires by randomly selecting the participating students. The responses were used to establish a multi-variate regression model where the relationships were established. The model suggested that information quality, system quality, and service quality had positive impacts on user satisfaction with the $p$-values of 0.014 , 0.014 , and 0.000 respectively. In addition, the study also found that user satisfaction was strongly and positively affected by the net benefits.
\end{abstract}

Keywords: E-learning; Binus Online Learning; DeLone and McLean IS Success Model

\section{INTRODUCTION}

Information technology has provided us opportunity to learn and access information easily [1]. IT has created a new way for learning beyond traditional classroom-based learning. IT has been considered to be able to improve learning quality at a lower cost than that required by the traditional learning method. The use of IT in education is more generally known as e-learning and is believed to be cost-effective and

Received: July 11, 2015; received in revised form: Aug. 15, 2015; accepted: July 1, 2015; available online: July 7, 2015. efficient. E-learning is a generic term to represent lecturing using any electronic media such the Internet, audio, interactive TV, etc [2].

According to Ref. [2], e-learning has been started since 1960s. It was firstly deployed by the University of Illinois. By 1980s, softwares have been widely used to support e-learning. In 1990s, University of Phoenix started long distance education using e-learning.

E-learning, knowledge management in general, has been developed and recognized as a self-contained discipline for years [3]. E-learning is focused on new knowledge and technology to support the learning construction process [4]. The integration of elearning with knowledge management is handled on the basis of the knowledge spiral model, developed by Nonaka and Takeuchi in 1995 [5]. According to this model, organizational knowledge is created with interactions/conversions, which take place continuously between tacit and explicit knowledge. There are many common features characteristic shared between e-Learning system and knowledge management. Reference [6] explained common characteristic in the process of e-learning system and knowledge management system, such as collaboration, project development, helpdesk, Learning Objects (LOs) use for presentation of learning content and knowledge, and Content Management Systems (CMS). E-learning and knowledge management also have spesific differences. E-learning systems try to provide structured learning contents and intercommunication possibilities to specific topics. On the other side, knowledge management systems provide knowledge through content management systems, which have search and sort facilities, and also collaboration possibilities with experts and other users on various topics [7].

Bina Nusantara University is the first university in 
Cite this article as: Yosep, "Analysis of relationship between three dimensions of quality, user satisfaction, and e-learning usage of Binus Online Learning," CommIT (Communication \& Information Technology)

Journal 9(2), 67-72, 2015.

Indonesia that receive government approval to manage

long-distance education. The approval was received on

June 2014. Previously, the university has been years using e-learning to support teaching and learning. Since 2001, the university has adopted and implemented multi-channel learning using a learning management system (LMS), so called Binusmaya. Since that, the LMS has been deployed and able to serve about 30000 active students per semester.

The long-distance education has received a wide acceptance particularly from professionals, entrepreneurs, and those who have obstacles to attend traditional university.

The Binus learning management system has been an essential component for the university to manage longdistance teaching and learning activities. However, despite of importance, the system lacks assessments related to its quality and the level of satisfaction of the users.

\section{THEORIES}

\section{A. E-learning}

E-learning is defined as a structural learning method by using electronic system or computer to support learning process [8]. E-learning has the following features. It is able to store and transmit learning materials using CD-ROM, external memory, servers on the Internet, and/or intranet. It includes content relevant to the learning objectives. It uses media elements such as words and pictures to deliver the contents. It uses instructional methods such as examples, practice, and feedback to promote learning. It may be instructorled (synchronous e-learning) or designed for self-paced individual study (asynchronous e-learning). It helps learners build new knowledge and skills linked to individual learning goals or to improved organizational performance. The goal of e-learning is to build transferable knowledge and skills linked to organizational performance or to help individuals achieve personal learning goals

\section{B. Information Systems Success Models}

The current work adopts DeLone and McLean's IS success model [9]. The model is depicted in Fig. 1. DeLone and McLean model contains six major dimensions of Information System (IS) success: system quality, information quality, use, user satisfaction, individual impact, and organizational impacts. The extended of DeLone and McLean model was introduced on 2003, with additional service quality dimension. DeLone and McLean model can be used to investigate IS usage and success, and examine the relationship

between system quality, information quality, and user satisfaction [9].

A numbers of studies on e-learning have been made to modify the Delone and McLean model. For example, Tella re-specified the IS model to evaluate the effectiveness of e-learning systems at the University of Botswana. The study concluded that content quality, system quality, support service quality, teaching and learning quality, self-regulated learning, intention to use, user satisfaction, and net benefits were important factors for evaluating the success of e-learning content management systems [10].

Based on the expectancy disconfirmation theory (EDT) and IS success model, Ref. [1] proposed a decomposed technology acceptance model in the context of an e-learning service. The study found that users' continuing intention to use e-learning system was determined by satisfaction, which in turn is jointly determined by perceived usefulness, information quality, confirmation, service quality, system quality, perceived ease of use and cognitive absorption. Reference [11] also investigated the relationship between user satisfaction and e-learning system using Structural Equation Model (SEM).

The DeLone and McLean IS Model Success is the most influential theories in predicting and explaining system use, user satisfaction, and IS success. The base IS Success model consists of six dimensions: system quality, information quality, systems use, user satisfaction, individual impact, and organizational impact. System quality and information quality affect both use and user satisfaction. Additionally, the amount of use can affect the user satisfaction. Use and user satisfaction are direct affected to individual impact; and individual performance will have some organizational impact.

DeLone and McLean proposed an updated IS Success model and evaluated its usefulness in light of the dramatic changes in IS practice. The IS Success model was updated by adding "service quality" measures as a new dimension and grouping all the "impact" measures into a single impact or benefit construct, called as "net benefit". Thus, the updated model consists of

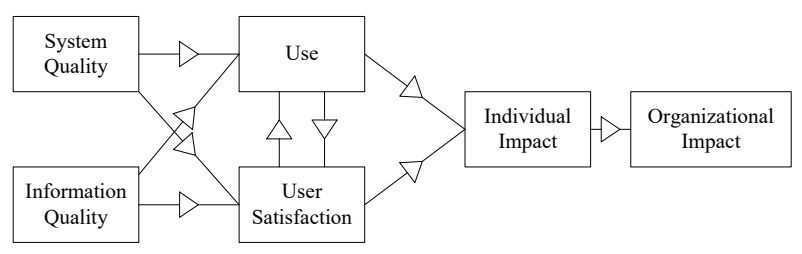

Fig. 1. IS Success Model DeLone and McLean [9]. 
Cite this article as: Yosep, "Analysis of relationship between three dimensions of quality, user satisfaction, and e-learning usage of Binus Online Learning," CommIT (Communication \& Information Technology)

Journal 9(2), 67-72, 2015.

six dimensions: information quality, system quality, service quality, use/intention to use, user satisfaction, and net benefits. Using the updated IS Success model, author modified the model for adjustments research environment [9].

1) Information Quality: Information quality (IQ) is a term to describe the quality of the content of information system. Information quality is the main factor that increases or decreases the efficiency of information systems including e-learning system. It evaluates the impacts of these dimensions and the efficiency of e-learning system. Information quality traditionally refers to measures of system output, namely the quality of the information that the system produces primarily in the form of reports.

In the recent literature, e-learning has been defined in different ways and its applicability domain may also vary. In fact it is important for any publication in the elearning field to ensure that the author's understanding matches exactly that of the majority of the readers; for this reason an agreed definition should be stated first. To reach a clearer understanding of what e-learning is, in the previous section, we presented a review of the major historical definitions of e-learning as mentioned in the literature. However, the position adopted in our study is that e-learning involved the technology used to distribute the learning materials, the quality of these materials, and the interaction with learners. The definition of e-learning used in this research addresses these dimensions in terms of:

Information quality is an important factor for the adoption of services. The selected information quality elements are: completeness, understandability, security, availability, and accuracy [12].

2) System Quality: System quality is the individual perception of a system's performance. From an elearning perspective, the system quality is measured in terms of both the hardware available to the user and the various software applications designed for their intended use and needs. Measures of System Quality typically focus on performance characteristics of the system under study. Nowadays quality is considered as a major issue for modern education in general, especially for e-learning the quality system could be a key success factor. Moreover, quality of e-learning system cannot be expressed and set by a simple definition without understanding the details, since the term quality is a very abstract notion and bear various dimension such as information quality, service quality, system quality. Some researchers had looked at resource utilization and investment utilization, reli- ability, response time, aggregation of details, human factors, and system trust and accuracy. In this work, the selected system quality elements are reliability, usability, adaptability, trust, and maintainability [12].

3) Service Quality: Service quality is the quality of the support that system users receive from the IS department and IT support personnel such as responsiveness, accuracy, reliability, technical competence, and empathy of the personnel staff. Universities worldwide must face, among other challenges, an increasingly differentiated demand for education, the need to carry out more commercial activities in order to obtain new sources of funding, and new competitors that make use of Information Technologies (ITs) to offer their educational services in a global market. All together, these factors are forcing universities to rethink their traditional roles, to develop new organizational structures and to reposition themselves through strategic direction setting. These trends and the widespread recognition that the universitys invisible product, knowledge, is the most important factor in economic and social growth are the reasons for the increasing competitiveness inside the higher education market all over the world. To be successful in this environment, universities should focus on customers' perceptions of service quality, understanding 'service' in the broad sense, including both academic and non academic services, since those perceptions are a key influence on students' decisions when they are choosing or recommending a particular institution. The elements of service quality are integrity, functionality, and efficiency [12].

4) User Satisfaction: User satisfaction is a measure of the successful interaction between an information system and its users. Delone and Mclean have addressed the subject of user satisfaction in their research. They concluded that user satisfaction was widely used as a measure of IS success. User satisfaction is widely accepted as a desirable outcome of any product or service experience because it is one of the most significant criteria for measuring IS success. In most studies on IT success, it is a factor to monitor the product or service quality and also to predict behavioural consequences. Satisfaction is an overall affective response to a perceived discrepancy between prior expectations and perceived performance after consumption. These elements are self-efficacy, repeat visits, personalization, and enjoyment [12].

\section{Net Benefit}

As the "impacts" of IS have evolved beyond the immediate user, researchers have suggested additional IS impact measures, such as work group impacts, interorganizational and industry impacts, consumer impacts, 
Cite this article as: Yosep, "Analysis of relationship between three dimensions of quality, user satisfaction, and e-learning usage of Binus Online Learning," CommIT (Communication \& Information Technology)

Journal 9(2), 67-72, 2015.

and societal impacts. Clearly, there is a continuum of ever-increasing entities, from individuals to national economic accounts, which could be affected by IS activity. The choice of where the impacts should be measured will depend on the system or systems being evaluated and their purposes. Rather than complicate the model with more success measures, we prefer to move in the opposite direction and group all the "impact" measures into a single impact or benefit category called "net benefits." The elements of the net benefit are quality concern, enhanced learning, time saving, and academic success.

\section{RESEARCH METHODS}

The current work utilized the modified DeLone and McLean IS Success Model [9]. The model is shown in Fig. 2. Thus, the four will-be-evaluated hypotheses are of the following:

- $\mathrm{H}_{1}$ : Information quality has positive impacts on user satisfaction.

- $\mathrm{H}_{2}$ : System quality has positive impacts on user satisfaction.

- $\mathrm{H}_{3}$ : Service quality has positive impacts on user satisfaction

- $\mathrm{H}_{4}$ : User satisfaction has positive impacts on net benefit.

A checklist instrument contains 22 measurement items is provided to a sample of students enrolling in online programs of Bina Nusantara University. The survey contain questions related to demographic, three dimensions of quality, user satisfaction, and net benefit. All items utilized Likert scale ranging from 1 to 5 denoting the state of "strongly disagree" to "strongly agree."

The checklist instrument is distributed to the entire students enrolling in the online programs of Bina $\mathrm{Nu}$ -

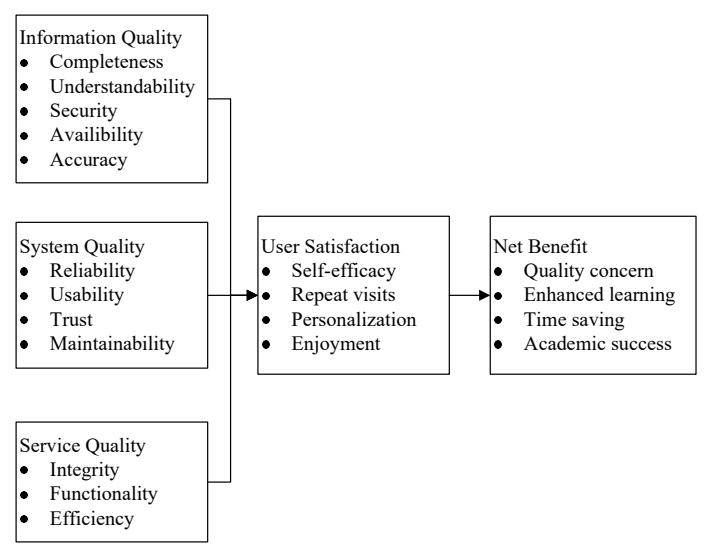

Fig. 2. The Modified DeLone and McLean IS Success Model [9]. santara University during Septermber until November 2015. Only 149 students fill the questionnaires, a 47.9 percent response rate.

A multivariate regression model is established to evaluate the relation among the variables of interest. The model coefficients and evaluation are performed using SPSS statistical analysis package.

\section{RESULTS AND DISCUSSION}

\section{A. Measure of Construct Validity and Reliability}

The validity test is performed using the Pearson's correlation coefficient. The results of the validity test are presented in Table I. We note thhat the indicator is assumed to be valid if $R_{\text {cal }}$ is bigger than 0.210 , which is the value of the $R_{\text {table }}$ for the number of respondents of 149 persons at $1 \%$ significance level.

The reliability test is evaluated using Cronbach's $\alpha$. The results are depicted in Table II. A variable is considered reliable if its Cronbach's $\alpha$ has a value larger than 0.6

TABLE I

The Results of the VAlidity Test.

\begin{tabular}{lll}
\hline Variable & Indicator & $R_{\text {cal }}$ \\
\hline Information Quality & Completeness & 0.755 \\
& Understandability & 0.753 \\
& Security & 0.526 \\
& Availability & 0.754 \\
& Accuracy & 0.645 \\
\hline System Quality & Reliability & 0.757 \\
& Usability & 0.740 \\
& Trust & 0.710 \\
& Maintainability & 0.742 \\
\hline Service Quality & Integrity & 0.791 \\
& Functionality & 0.778 \\
& Efficiency & 0.679 \\
\hline User Satisfaction & Self-efficacy & 0.717 \\
& Repeat visits & 0.676 \\
& Personalization & 0.682 \\
& Enjoyment & 0.736 \\
\hline Net Benefit & Quality concern & 0.790 \\
& Enhanced learning & 0.745 \\
& Time saving & 0.717 \\
& Academic success & 0.756 \\
\hline
\end{tabular}

TABLE II

The Results of the Reliability Test.

\begin{tabular}{lcc}
\hline Variable & Cronbach- $\alpha$ & Result \\
\hline Information Quality & 0.725 & Reliable \\
System Quality & 0.714 & Reliable \\
Service Quality & 0.613 & Reliable \\
User Satisfaction & 0.656 & Reliable \\
Net Benefit & 0.740 & Reliable \\
\hline
\end{tabular}


Cite this article as: Yosep, "Analysis of relationship between three dimensions of quality, user satisfaction, and e-learning usage of Binus Online Learning," CommIT (Communication \& Information Technology)

Journal 9(2), 67-72, 2015.

\section{B. The Measure of Multicollinearity}

The results of multicollinearity tests are shown in Table III where Tolerance and Variance Inflation Factor (VIF) are used to measure the collinearity. Tolerance is an indication of the percent of variance of the predictor that cannot be accounted for by the other predictors; hence, a very small value of Tolerance indicates that the predictor is redundant. The value of Tolerance less than 0.10 may merit further investigation. The VIF is inversely proportional to Tolerance. A rule of thumb, the value of VIF that greater than 10 may merit further investigation. Thus, no multicollinearity is detected.

\section{Measure of Normality}

The residue of a regression model should be distributed normally to justify the regression model. Figures 3 and 4 show that the assumption is justified.

\section{Regression Analysis}

The results of the regression analysis relating the dependent variable User Satisfaction and the independent variables Information Quality, System Quality, and Service Quality are shown in Table IV. The $t$-test results in the table suggest that the three independent variables are independently significant. The $F$-test results suggest that the three independent variables are simultaneously significant.

TABLE III

The Results of Multicollinearity Test.

\begin{tabular}{llcc}
\hline Variable & Indicator & Tolerance & VIF \\
\hline \multirow{2}{*}{ Information Quality } & Completeness & 0.673 & 1.485 \\
& Understandability & 0.640 & 1.562 \\
& Security & 0.889 & 1.125 \\
& Availability & 0.638 & 1.567 \\
& Accuracy & 0.824 & 1.213 \\
\hline \multirow{2}{*}{ System Quality } & Reliability & 0,657 & 1.522 \\
& Usability & 0.628 & 1.593 \\
& Trust & 0.793 & 1.261 \\
& Maintainability & 0.702 & 1.425 \\
\hline \multirow{2}{*}{ Service Quality } & Integrity & 0,755 & 1.324 \\
& Functionality & 0.791 & 1.265 \\
& Efficiency & 0.875 & 1.143 \\
\hline User Satisfaction & Self-efficacy & 0.788 & 1.270 \\
& Repeat visits & 0.831 & 1.203 \\
& Personalization & 0.745 & 1.342 \\
& Enjoyment & 0.709 & 1.410 \\
\hline Net Benefit & Quality concern & 0.627 & 1.595 \\
& Enhanced learning & 0.702 & 1.425 \\
& Time saving & 0.788 & 1.270 \\
& Academic success & 0.679 & 1.472 \\
\hline
\end{tabular}

Thus, the established regression model is

$\mathrm{US}=0.727+0.319 \cdot \mathrm{IQ}+0.175 \cdot \mathrm{Sys} Q+0.316 \cdot \mathrm{SerQ}$

where US denotes User Satisfaction, IQ denotes Information Quality, SysQ denotes Service Quality and SerQ denotes Service Quality. The model suggests that the aspect Information Quality and Service Quality is twice as important as the System Quality.

In addition, we also evaluate the relation between

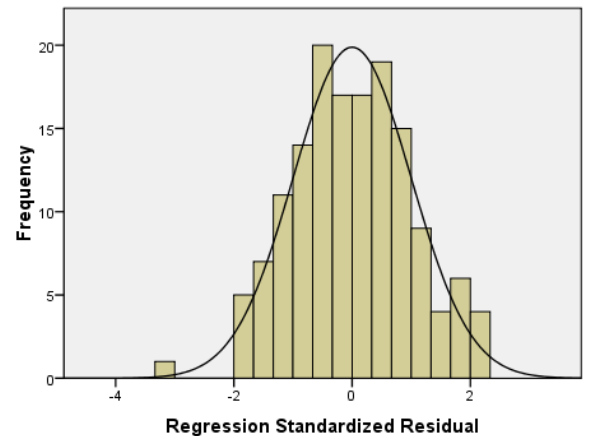

Fig. 3. Histogram of the model residue.

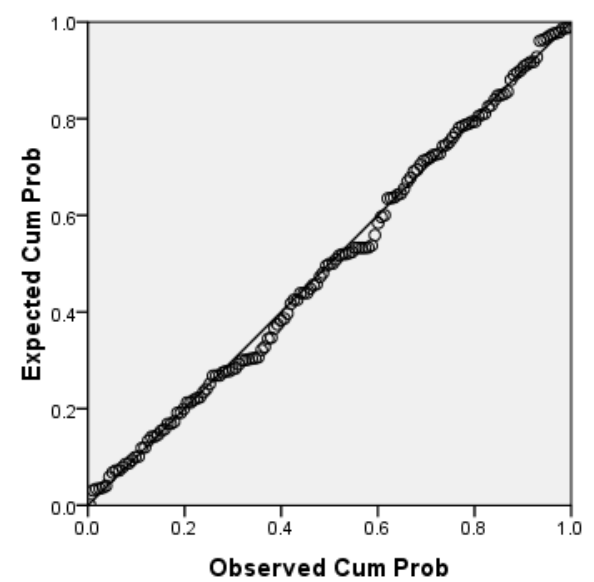

Fig. 4. QQ-plot of the mode residue.

TABLE IV

The Results of Multiple Regression Analysis Relating USER SATISFACTION TO INFORMATION QUALITY, SYSTEM QUALITY, AND SERVICE QUALITY.

\begin{tabular}{lrrr}
\hline & Reg. Coef. & $t$-stat & $p$-value \\
\hline Constant & 0.727 & 3.705 & 0.000 \\
Information quality & 0.319 & 3.726 & 0.014 \\
System quality & 0.175 & 2.485 & 0.014 \\
Service quality & 0.316 & 4.773 & 0.000 \\
& & & \\
Adjusted $R^{2}$ & 0.572 & & \\
$F$-value & 67.036 & & \\
$p$-value & 0.000 & & \\
\hline
\end{tabular}


Cite this article as: Yosep, "Analysis of relationship between three dimensions of quality, user satisfaction, and e-learning usage of Binus Online Learning," CommIT (Communication \& Information Technology)

Journal 9(2), 67-72, 2015.

TABLE V

The Results of Multiple Regression Analysis Relating NET BENEFITS TO USER SATISFACTION.

\begin{tabular}{lrrr}
\hline & Reg. Coef. & $t$-stat & $p$-value \\
\hline Constant & 1.105 & 4.899 & 0.000 \\
User Satisfaction & 0.699 & 10.872 & 0.000 \\
& & & \\
Adjusted $R^{2}$ & 0.442 & & \\
$F$-value & 118.206 & & \\
$p$-value & 0.000 & & \\
\hline
\end{tabular}

User Satisfaction and Net Benefits (NB) and the results are presented in Table $\mathrm{V}$.

Thus, the simple regression model for the two variables is

$$
\mathrm{NB}=1.105+0.699 \cdot \mathrm{US},
$$

where NB represent Net Benefit. This involved variables in the model are also statistifically significant.

The above analysis leads us to the following conclusions:

- $\mathrm{H}_{1}$ that information quality has positive impacts on user satisfaction is accepted,

- $\mathrm{H}_{2}$ that system quality has positive impacts on user satisfaction is accepted,

- $\mathrm{H}_{3}$ that service quality has positive impacts on user satisfaction is accepted, and finally

- $\mathrm{H}_{4}$ that user satisfaction has positive impacts on net benefits is also accepted.

\section{CONCLUSIONS}

Bina Nusantara University has been approved by the government of Republic of Indonesia to manage longdistance education. To manage the education programs, the university has developed and utilized a learning management system so called Binusmaya. This study is performed to understand the user acceptance and related variables of the system. The study adopted DeLone and McLean's IS success model and utilized empirical data collected from a sample of 75 students of 311 total enrolled students by using questionnaires. The model suggests that the level of user satisfaction of the system is affected by the aspects of information quality, system quality, and service quality. Subsequently, the user satisfaction is affected by the net benefits. The collected data are used to establish regression models, and the models suggest that the relationships are proven to be significant.

\section{REFERENCES}

[1] J. C. Roca, C.-M. Chiu, and F. J. Martínez, "Understanding e-learning continuance intention: An extension of the technology acceptance model,"
International Journal of human-computer studies, vol. 64, no. 8, pp. 683-696, 2006.

[2] C. C. Weggen and T. A. Urdan, Corporate E-learning: Exploring A New Frontier. WR Hambrecht and Co, 2000. [Online]. Available: www.wrhambrecht.com/research/coverage/ elearning/idirexplore.html

[3] J. Judrups, "Analysis of knowledge management and e-learning integration models," Procedia Computer Science, vol. 43, pp. 154-162, 2015.

[4] R. Mihalca, A. Uta, A. Andreescu, and I. Intorsureanu, "Knowledge management in elearning systems," Revista Informatica Economică, vol. 46, no. 2, pp. 60-65, 2008.

[5] I. Nonaka and H. Takeuchi, The knowledgecreating company: How Japanese companies create the dynamics of innovation. Oxford university press, 1995.

[6] K. Yordanova, "Integration of knowledge management and e-learning: Common features," in Proceedings of the 2007 international conference on Computer systems and technologies. ACM, 2007, p. 94.

[7] A. Ausserhofer. (2002) Elearning and knowledge management towards lifelong education. Austria: Graz University of Technology. [Online]. Available: http://citeseerx.ist.psu.edu/viewdoc/download? doi=10.1.1.195.1299\&rep=rep1\&type $=$ pdf

[8] R. C. Clark and R. E. Mayer, E-learning and the science of instruction: Proven guidelines for consumers and designers of multimedia learning. John Wiley \& Sons, 2011.

[9] W. H. Delone and E. R. McLean, "The delone and mclean model of information systems success: a ten-year update," Journal of management information systems, vol. 19, no. 4, pp. 9-30, 2003.

[10] A. Tella, S. Mutula, A. Mutshewa, and A. Totolo, "An evaluation of webct course content management system at the university of botswana," $E$ Adoption, vol. 2, no. 2, pp. 205-232, 2012.

[11] T. Ramayah and J. W. C. Lee, "System characteristics, satisfaction and e-learning usage: A structural equation model (sem)," TOJET: The Turkish Online Journal of Educational Technology, vol. 11, no. 2, 2012.

[12] S. Petter, W. DeLone, and E. McLean, "Measuring information systems success: models, dimensions, measures, and interrelationships," $\mathrm{Eu}$ ropean journal of information systems, vol. 17, no. 3, pp. 236-263, 2008. 